\title{
THE EFFECT OF DEBT TO EQUITY RATIO AND RETURN ON EQUITY ON STOCK RETURN WITH DIVIDEND POLICY AS INTERVENING VARIABLES IN SUBSECTORS PROPERTY AND REAL ESTATE ON BEI
}

\author{
Dina Nurhikmawaty ${ }^{1}$ Isnurhadi $^{2}$, MarlinaWidiyanti $^{3}$, Yuliani $^{4}$ \\ ${ }^{1234}$ Magister Programme of Management, Faculty of Economics, UniversitasSriwijaya, \\ 1nurhikmawatydina@ymail.com, ${ }^{2}$ Isnurhadi2020@gmail.com, ${ }^{3}$ marlinawidiyanti68@yahoo.co.id, \\ 4yulianisyapril@unsri.ac.id
}

\begin{abstract}
Debt to Equity Ratio (DER) and Return on Equity (ROE) to stock returns with dividend policy as an intervening variable on property and real estate companies listed on the Indonesia Stock Exchange in 2014-2018. This type of research is quantitative. This research population publishes all property and real estate companies listed on the Indonesia Stock Exchange. The sampling technique used is purposive sampling. The data contributed to the research of 54 companies, and obtained a sample of 18 companies. Data analysis method used is path analysis (path analysis) using the multiple test. Based on the results of data analysis, it shows that: (1) Debt to Equity Ratio (DER) does not affect stock returns; (2) Return on equity (ROE) has a significant effect on stock returns; (3) Debt to Equity Ratio (DER) has a significant effect on Dividend Payout Ratio (DPR); (4) Return on equity (ROE) has a significant effect on Dividend Payout Ratio (DPR); (5) Dividend Payout ratio (DPR) can mediate the effect of Debt to Equity Ratio (DER) on stock returns; (6) Dividend payout ratio (DPR) can mediate the effect of return on equity (ROE) on stock returns.
\end{abstract}

Keywords:Debt to Equity Ratio (DER), Return on equity (ROE), Stock Returns, Dividend Payout Ratio (DPR), Dividend Policy

\section{Introduction}

Economic development at this time resulted in increasingly fierce business competition. For that, every company must be more leverage and always be more careful in running the company to obtain the profit or profit expected by the company. As the economy grows, the property and real estate industries also develop.

At present, the profits earned by property companies listed on the IDX are experiencing a decline in aspects of their financial statements. This resulted in a lot of impact experienced by the company. This is caused by various factors that occur. However, property companies listed on the IDX still make the best contribution to consumers. The decline in several aspects of financial statements experienced by property companies due to the impact of the existing global financial crisis. There is also a depreciation in the rupiah and an increase in fuel prices which has caused uncertainty and rising inflation. This has resulted in doubts and delays in investing in the private sector and eroding national economic resilience(Pratiwi, 2018).

Research in the property sector is said to be important because the need for boards is one of the basic human needs. Activities in the property industry can be used as an indicator of how active economic activity is taking place. Every economic activity basically will always require property products as a factor of production. The development of property activities has a multiplier effect on the development of other sectors that are directly or indirectly related. In the case if there is no demand for property products, it indicates that the economy is in an underdeveloped condition. Property is arguably the sector that never dies. When other sectors collapsed due to economic crisis, the property business showed an anomaly. In various

DOI: 10.33603/ejpe.v8i2.3531 
places, there are houses and shophouses, apartments, shopping centers, office centers, condominiums and housing (Pratiwi, 2018).

The phenomenon that is developing at this time illustrates that the real estate and property sub-sector is a business sub-sector that is sufficiently developing. Latest news about companies in the real estate and property sub-sector, where an increase in profits in the real estate and property sub-sector reached $43 \%$ (Komala, L. A. P., \& Nugroho, P. I., 2013). The increase rate is higher than the chemical industry and investment services which only $41 \%$ and $34 \%$. The increase in profits was based on rising demand and rising property prices by $5.17 \%$ per year.

This condition is the main consideration of researchers to choose the property and real estate sector as research objects. On the Indonesia Stock Exchange (IDX) 54 real estate companies are listed. Researchers used a purposive sampling method that focused on 18 Real Estate and Property companies found on the IDX. This research period was conducted between 2014-2018, with the reason that the period is the period closest to the time of the study, the availability and completeness of the data in this period also became one of the period selection variables.

The financial ratios used in this study are solvency ratios that are proxied in Debt to Equity Ratio (DER), and profitability ratios proxied in Return on Equity (ROE). Debt to Equity Ratio (DER) is a ratio that shows how much proportion of the company's capital comes from debt. The higher the DER, the higher the risk that will occur to the company, because the company's funding from the debt element is greater than its own capital.

One of the most important indicators used by investors to increase the value of profitability itheir companies before investing is to know the amount of Return on Equity (ROE) in a company. ROE is a measure of a company's ability to generate profits using its own capital(Susilowati \& Turyanto, 2011). ROE ratio can be used to show the level of returns generated by management from the capital provided by the owner of the company itself.DER and ROE have an important role in dividend policy, where this policy can ultimately maximize stock returns. The results of research on what factors can influence the return of special shares in ROE, DER, still produce inconsistent findings (see for example (Nurmasari, 2017); (Siburian, 2013); (Nazir et al., 2012); (Yudiana \& Yadnyana, 2016); (Baah et al., 2014); (Unggul, 2013). Based on Nurmasari's and Nazir's finding, the results showed that partially, CR, ROE and income growth had no significant effect on stock returns. Meanwhile, DER has a significant negative effect on stock returns. Financial ratios (CR, ROE, DER) and income growth simultaneously have a significant effect on stock returns. While, Yudiana's finding shows that managerial ownership has no effect on dividend policy, while leverage and investment opportunity set negative effect on dividend policy, as well as a positive effect on profitability dividend policy. Further, Baah and Unggul found that The study reveals that the main determinants of dividend policies of companies listed on the GSE are return on equity, profit after tax and size of the company. There are however different factors that influence the dividend payout across the various sectors. Hence, further research needs to be done on the certainty of what factors can influence stock returns in capital markets with dividend policy as an intervening variable that mediates the relationship between DER and ROE. Therefore, based on the relationship between ROE and DER with dividend policy, the dividend policy is determined in this study as an intervening variable that mediates the relationship between DER and ROE with stock returns.

The results of research on what factors can influence stock returns specifically ROE, DER, still produce inconsistent findings. This can be seen from previous research conducted p-ISSN 2337-571X | e-ISSN 2541-562X

(C) 2020 Edunomic: Jurnal Ilmiah Pendidikan Ekonomi Fakultas Keguruan dan Ilmu Pendidikan 
by (Nurmasari, 2017) and (Siburian, 2013) which concluded that DER has no significant effect on stock returns. (Aziz, 2012) and (Susilowati \& Turyanto, 2011) state that Return On Equity has a positive and significant effect on stock returns. It is different from the research conducted by (Nurmasari, 2017) which states that ROE does not have a significant effect on stock returns. (Yudiana \& Yadnyana, 2016) show that leverage (DER) has a negative effect on dividend policy, and profitability (ROE) has a positive effect on dividend policy. (Unggul, 2013) states that there is an effect of profitability ratio (ROE) on stock returns with dividends as a mediating variable. (Nazir et al., 2012) stated that there is an effect of the leverage ratio (DER) on stock returns with dividends as a mediating variable. (Afas et al., 2017), (Komrattanapanya \& Suntraruk, 2013), (Labhane \& Das, 2015), and (Yasa \& Wirawati, 2016), show that DER has a significant (negative) effect on the dividend payout ratio where each increase of debt to equity ratio causes a decrease in the dividend payout ratio. Meanwhile, research results from (Rehman \& Takumi, 2012) show a significant (positive) result from the debt to equity ratio to the dividend payout ratio, where each increase in debt to equity ratio will cause an increase in the dividend payout ratio. (Gumanti, 2013), (Komala \& Nugroho, 2013), (Sumampow \& Murni, 2016), (Kartika, 2015), (Yudiana \& Yadnyana, 2016) and Yasa et al (2016). ) shows that ROE has a significant (positive) effect on the dividend payout ratio where an increase in return on equity results in an increase in the dividend payout ratio. While the results of research (Komala \& Nugroho, 2013) and (Maladjian \& Khoury, 2014) show a significant (negative) result of return on equity to dividend payout ratio, where each increase in return on equity will cause a decrease in the dividend payout ratio. Based on the description above, there is a research question from previous research, so that researchers are interested in reexamining the relationship between ROE and DER with dividend policy as an intervening variable that mediates the relationship between DER and ROE with stock returns.

\section{Literatur Review \\ Debt to Equity Ratio (DER)}

According to(Horne Van \& Wachowicz Jr, 2000), "Debt to Equity Ratio is a comparison between total debt or total debts with total shareholder's equity". This ratio is sought by comparing all debt, including current debt and all equity. For banks (creditors), the greater this ratio, the more unprofitable because the greater the risk borne by the failure that may occur in the company.

However, for companies the greater the ratio the better. Conversely with a low ratio, the higher the level of funding provided by the owner and the greater the security limit for the borrower in the event of loss or depreciation of the value of the asset. This ratio also provides general guidance on the financial viability and risk of the company. The formula to look for debt to Equity Ratio is as follows:

$$
\text { Debt to Equity Ratio }=\frac{\text { TotalLiabilities }}{\text { ShareholdersEquity }}(\text { Shim \& Siegel, 1999) }
$$

\section{Return on Equity (ROE)}


According to(Brigham \& Houston, 2011), the notion of ROE is the net ratio of ordinary equity measures the rate of return on ordinary shareholder investment. This Return on Equity Ratio shows the efficient use of own capital. If this ratio is higher, the better. That means the company's position will be stronger, and vice versa. Return on Equity is calculated by dividing net income with shareholder equity. How to calculate return on equity can be done by using a formula. The following is the Return on Equity (ROE) formula:

$$
\text { Return On Equity }=\frac{\text { NetIncome }}{\text { Equity }}(\text { Van Horne \& Wachowicz Jr, 2005) }
$$

\section{Stock Return}

According to(Tandelilin, 2010)stock return is one of the factors that motivates investors to invest and is also a reward for the courage of investors to bear the risk of investing they do. According(Hartono, 2013) stock returns defined the results obtained from stock investments. Returns can be either realized returns that have occurred or expected expectations that have not yet occurred but are expected to occur in the future. According to(Brigham \& Houston, 2011), return is the difference between the amount received and the amount invested divided by the amount invested.

According to (Horne \& Wachowicz, 2012)return (return) is the income received from an investment coupled with changes in market prices, which is usually expressed as a percentage of the initial market price of the investment. Based on the above definition the authors conclude that stock returns are a result obtained or the difference between the amount received by the amount invested divided by the amount invested from selling or buying a stock. The following is the Stock Return formula;

\section{Dividend Policy}

$$
\text { Return }=\frac{P_{t}-P_{t-1}}{P_{t-1}}+\text { Yield (Ariyanti, 2016) }
$$

Dividend is the distribution of profits / profits made by a company to shareholders on the profits obtained by the company(Halim, 2015). Whereas dividend policy is a decision to divide the profits obtained by the company to shareholders as dividends or will retain in the form of retained earnings to be used as investment financing in the future.

If the company chooses to distribute profits as dividends, it will reduce retained earnings and then reduce the total source of internal funding or internal financing. Conversely, if the company chooses to hold the profits obtained, then the ability to form internal funds will be even greater (Sartono, 2014). Dividend payments differ from interest payments because dividends cannot reduce the amount of taxes paid by companies, because the funds are taken from net income after taxes (earning after taxes) (Syamsudin, 2011).

Dividend payout ratio measurement is a part that is integrated with the company's funding decision. Dividend Payout Ratio, which is the ratio that shows the results of the comparison between cash dividends per share and earnings per share.

This ratio illustrates the amount of profit from each share allocated in dividends. Similar to dividend yield, this ratio can also be used as a proxy (approach) in determining dividend policy, which is a decision making by the issuer regarding the amount of cash dividends to be distributed to shareholders (Hery \& Si, 2015). The following is the Dividend Payout Ratio (DPR)formula ;

$$
\mathrm{DPR}=\frac{\text { DividendPershare }}{\text { EarningPerShare }}(\text { Hery } \& \mathrm{Si}, 2015)
$$




\section{RESEARCH METHOD}

The type of data used in this study is quantitative data. Quantitative data is data in the form of numbers. Quantitative data used in this study is the company's 2014-2018 financial statements and annual reports obtained through the Indonesia Stock Exchange (IDX) website published on its website, namely www.idx.co.id and the websites of each company if the data is not obtained on the Indonesia Stock Exchange (IDX) website.

The scope of the problem that will be discussed in the writing of this thesis, namely researchers only discuss the Effect of Debt Equity Ratio and Return on Equity on stock returns with Dividend Policy as Intervening Variables in the Property and Real Estate subsector on the Indonesia Stock Exchange period 2014-2018.

According to the source, the data used in this study are primary data, primary data is a source of data obtained directly from the original source (not through intermediary media). The data used in this study are company publications in the form of financial reports, annual reports and a summary of the performance of the sample companies during the observation period.

The total sample of Real Estate and Property companies listed on the IDX has 54 companies while the samples taken are based on sample withdrawal characteristics that have sample research criteria of 18 companies.

\section{Analysis Method}

The data analysis method used in this study uses multiple linear regression with the help of the SPSS (Statistical Product and Service Solutions program) program. Based on the hypothesis in this study, the data analysis method used is quantitative analysis to calculate or estimate quantitatively from several factors individually or together with the related variables. The functional relationship between one variable related to the independent variable can be done with multiple linear regression.

Previous research was used as a reference in gathering variables in this study by(Sari, 2015). The results of this study are the Debt to Equity Ratio (DER) and Return on Equity (ROE). Research result. (Nirayanti \& Widhiyani, 2014)Different from the results of Good, (Priyonoto et al., 2018)research shows that the Current Ratio, Debt to Equity Ratio and Return on Equity are not significant to stock returns. The research framework is a relationship and the relationship between one concept to another concept of the problem to be studied. For this framework to connect and explain a topic to be discussed. This flow of thought is expected to provide direction and an overview of the variables to be examined. The variables that will be used in analyzing stock returns are financial ratios that include Debt to Equity Ratio and Return on Equity. The framework of research is described as follows; 


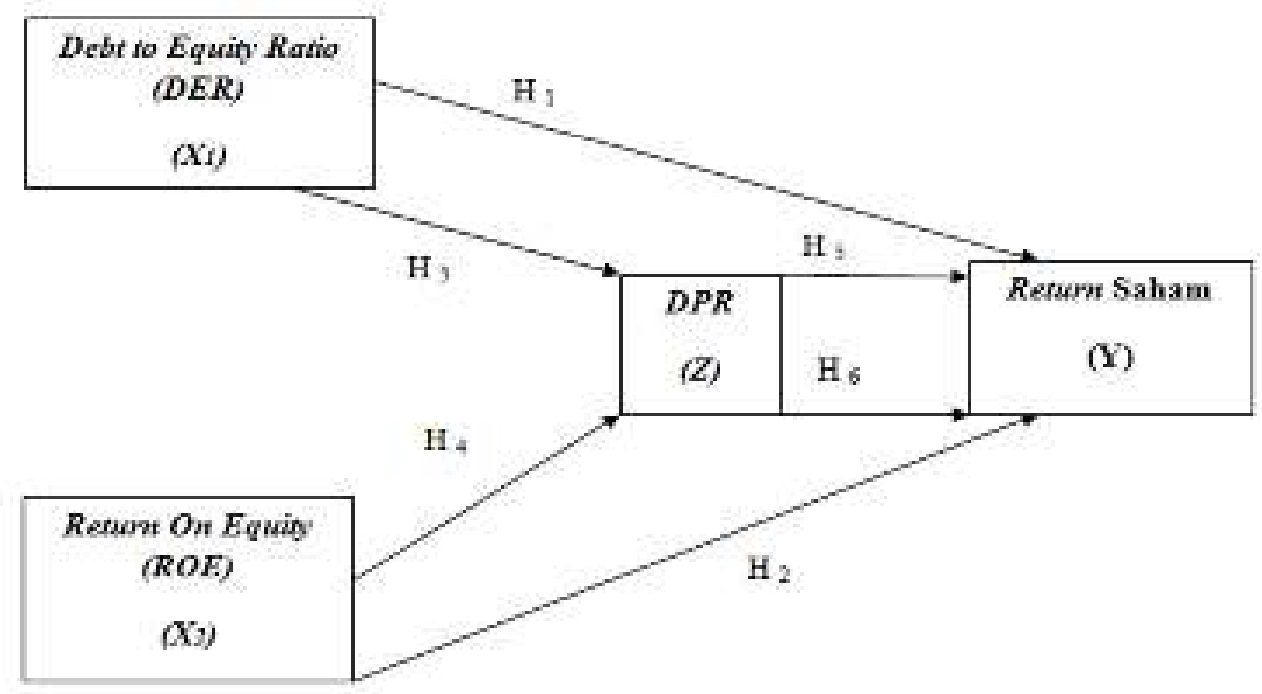

Figure 1. Research Framework

\section{Results and Discussion}

Hypotheses Test and Discussion

Effect of DER and ROE on DPR

Tabel 1. Partial T test

\section{Coefficients $^{\mathrm{a}}$}

\begin{tabular}{|c|c|c|c|c|c|}
\hline \multirow[t]{2}{*}{ Model } & \multicolumn{2}{|c|}{ Unstandardized Coefficients } & \multirow{2}{*}{$\frac{\text { Standardized Coefficients }}{\text { Beta }}$} & \multirow[t]{2}{*}{$\mathbf{t}$} & \multirow[t]{2}{*}{ Sig. } \\
\hline & B & Std. Error & & & \\
\hline (Constant) & 5.196 & .417 & & 12.450 & .000 \\
\hline 1 & & & & & \\
\hline LN_DER & .381 & .154 & .236 & 2.468 & 0.16 \\
\hline LN_ROE & .656 & .164 & .382 & 3.994 & .000 \\
\hline
\end{tabular}

a. Dependent Variable: LN_DPR

Based on the results of the partial $t$ test presented above, the following calculation results are obtained:

a. The variable Debt to equity Ratio (DER) has a significant effect on the DPRin property and real estate companies listed on the Indonesia Stock Exchange in the 2014-2018 period, this is evidenced by the coefficient sig $=0.016<0.05$.

b. The Return on Equity (ROE) variable has a significant effect on the DPRin property and real estate companies listed on the Indonesia Stock Exchange in the 2014-2018 period, this is evidenced by the coefficient sig $=0.000<0.05$. 


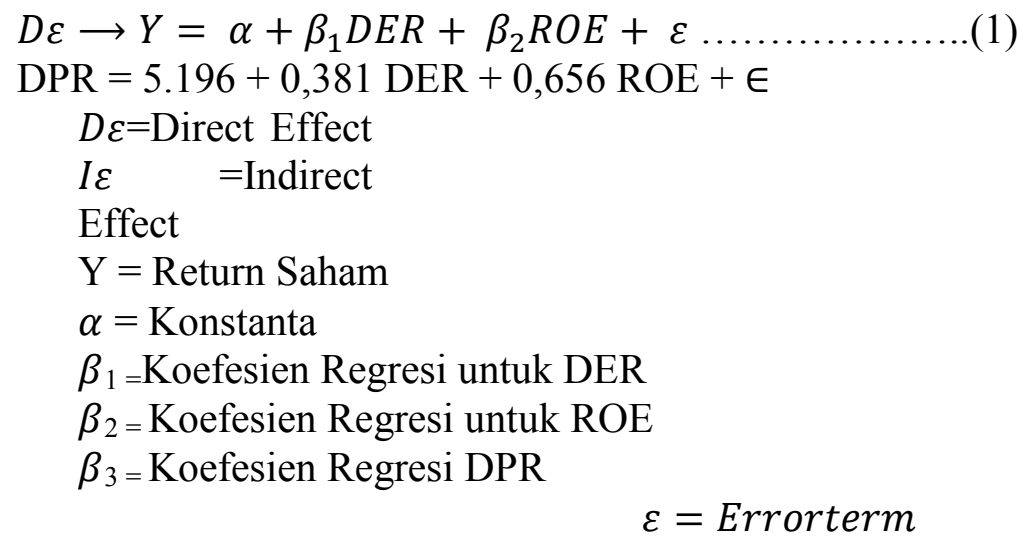

\section{Effect of DER, ROE and DPR on Stock Returns}

Tabel 2. Partial T Test

Coefficients $^{\mathrm{a}}$

\begin{tabular}{llcrrrrr}
\hline Model & \multicolumn{2}{c}{$\begin{array}{c}\text { Unstandardized Coefficients } \\
\text { B }\end{array}$} & $\begin{array}{c}\text { Std. Error } \\
\text { Standardized Coefficients } \\
\text { Beta }\end{array}$ & t & Sig. \\
\hline 1 & (Constant) & .920 & .529 & & 1.739 & .086 \\
& LN_DER & .236 & .121 & .139 & 1.949 & .055 \\
& LN_ROE & .632 & .136 & .349 & 4.656 & .000 \\
& LN_DPR & .549 & .081 & .521 & 6.740 & .000 \\
\hline
\end{tabular}

a. Dependent Variabel: LN_Return

Based on the test results presented above, the following research findings are obtained:

a. DER did not have an insignificant effect on Stock Returns in property and real estate companies listed on the Indonesia Stock Exchange in the 2014-2018 period, this finding was proven by the coefficient sig $=0.055>0.05$

b. ROE has a significant effect on Stock Returns in property and real estate companies listed on the Indonesia Stock Exchange in the 2014-2018 period, this finding is evidenced by the coefficient sig $=0.000<0.05$.

c. DPR has a significant influence on Stock Returns in property and real estate companies listed on the Indonesia Stock Exchange in the 2014-2018 period, this finding is proven by the coefficient sig $=0.000<0.05$.

$$
I \varepsilon \rightarrow Y=\alpha+\beta_{1} D E R+\beta_{2} R O E+\beta_{3} D P R+\varepsilon
$$$$
\text { Return }=0,920+0,236 \mathrm{DER}+0,632 \mathrm{ROE}+0,549 \mathrm{DPR}+
$$$$
\text { Keterangan: }
$$$$
D \varepsilon=\text { Direct Effect }
$$$$
\text { I } \varepsilon \quad=\text { Indirect }
$$$$
\text { Effect }
$$$$
\mathrm{Y}=\text { Return Saham }
$$$$
\alpha=\text { Konstanta }
$$$$
\beta_{1=\text { Koefesien Regresi untuk DER }}
$$ 
$\beta_{2}=$ Koefesien Regresi untuk ROE

$\beta_{3}=$ Koefesien Regresi DPR

$$
\varepsilon=\text { Errorterm }
$$

\section{DER Mediation Test of Stock Returns through the DPR with Sobel Test}

The Path Test is carried out using the Sobel Test with the help of the Sobel Calculator which is provided online at the website: http://quantpsy.org/sobel/sobel.htm ) and is known as the Sobel Test (Sobel Test). Sobel test is done by testing the indirect effect between independent variables on the dependent variable through intervening variables. To see the effect of mediation, it is seen from the multiplication coefficient that is significant or not. The following are mediation test results of the effect of DER on-stock returns through the DPR:

$$
\begin{aligned}
& S_{a b}=\sqrt{b^{2} S a^{2}+a^{2} S b^{2}+S a^{2} S b^{2}} \\
& =\sqrt{\left(0,549^{2} \times 0,154^{2}\right)+\left(0.380^{2} \times 0,081^{2}\right)+\left(0,154^{2} \times 0,081^{2}\right)} \\
& =\sqrt{(0.301401 \times 0,023716)+(0,1444 \times 0,006561)+(0,023716 \times 0,006561)} \\
& =\sqrt{(0,0071480261+0,0009474084+0,0001556007)} \\
& =0,090835209 \\
& =\frac{a b}{S a b} \\
& =\frac{0.380 \times 0,549}{0,090835209}=\frac{0,20862}{0,09083}=2,2968
\end{aligned}
$$

From the results of $t$ count $=2.296$ greater than $t$ table with a significance level of 0.05 that is equal to 1.96 , it can be concluded that the mediation coefficient 0.20862 is significant and means there is an effect of DER mediation on stock returns through the DPR.

\section{ROE Mediation Test of Stock Returns through the DPR with Sobel Test}

The Path Test is carried out using the Sobel Test with the help of the Sobel Calculator which is provided online at the website: http://quantpsy.org/sobel/sobel.htm ) and is known as the Sobel Test (Sobel Test). Sobel test is done by testing the indirect effect between independent variables on the dependent variable through intervening variables. To see the effect of mediation, it is seen from the multiplication coefficient that is significant or not. The following are mediation test results of the effect of ROE on stock returns through the DPR:

$$
\begin{aligned}
& S_{a b}=\sqrt{b^{2} S a^{2}+a^{2} S b^{2}+S a^{2} S b^{2}} \\
& =\sqrt{\left(0,549^{2} x 0,164^{2}\right)+\left(0.656^{2} \times 0,081^{2}\right)+\left(0,164^{2} \times 0,081^{2}\right)} \\
& =\sqrt{(0.301401 \times 0,026896)+(0,1444 \times 0,006561)+(0,026896 \times 0,006561)} \\
& =\sqrt{(0,0081064813+0,0009474084+0,0001764647)}
\end{aligned}
$$




$$
\begin{aligned}
& =0,0960747334 \\
& t=\frac{a b}{S a b} \\
& =\frac{0,656 \times 0,549}{0,09607}=\frac{0,36014}{0,09607}=3,748
\end{aligned}
$$

From the results of $t$ count $=3.748$ is greater than $t$ table with a significance level of 0.05 which is 1.96 , it can be concluded that the mediation coefficient of 0.3601 is significant and means there is an effect of ROE mediation on stock returns through the DPR.

\section{Effect of DER on-Stock Return}

Statistical test results with the test showed that the DER variable (Debt to Equity Ratio) did not have a significant effect on stock returns on property and real estate companies listed on the Indonesia Stock Exchange in the 2014-2018 period, this finding was evidenced by the coefficient sig $=0.055>0.05$.

The higher the value of DER, the more equity funding through debt. This indicates that the capital structure of the business more use of debts. The increase in DER can also be caused by the value of own capital is much smaller when compared to debt on external parties. Increasing the use of debt will increase company capital but if the company is unable to manage these funds effectively and efficiently, so a high debt equity ratio will reflect the high debt held by the company. If the company's Debt to Equity Ratio (DER) is high, there is a possibility that the company's stock price will be low because if the company makes a profit, the company tends to use that profit to pay its debt compared to dividing the dividend.

This situation will certainly provide bad information for investors. If a company bears a high debt burden, that is, exceeds its own capital, then the company's stock price will decrease. This bad information will cause a decrease in stock demand, so the stock price will make adjustments to the information that has been circulating. This means that most manufacturing companies are considering empowering their own capital as a source of funding. These conditions will cause the stock returns obtained by investors will decrease.

The results of this study support research conducted by(Nurmasari, 2017) examining the effect of DER on stock returns in mining companies concluding that DER does not have a significant effect on stock returns. This research is also supported by (Siburian, 2013)concluding that DER does not have a significant effect on stock returns.

\section{Effect of Return on Equity (ROE) on Stock Returns}

Obtained a coefficient of the ROE variable of 0.632 and has a significance value of 0.000 . Where the value is smaller than the significance value $(\alpha=0.05)$. Then the Return on Equity (ROE) has a significant positive effect on stock returns. These results indicate an increase and decrease in stock returns will be influenced by Return on Equity information. This ratio illustrates the rate of return on own capital in generating net income. If the Property and Real Estate company shows an increase in ROE, then the company has good management in managing its capital optimally to generate net profit. So that it can improve the welfare and trust of investors who invest their capital in the Property and Real Estate company.

Investor confidence will be followed by increased demand for these shares. Then the request will be followed by a rising stock price and then the stock return that will be obtained

\footnotetext{
p-ISSN 2337-571X | e-ISSN 2541-562X

(C) 2020 Edunomic: Jurnal Ilmiah Pendidikan Ekonomi Fakultas Keguruan dan Ilmu Pendidikan
} 
will also increase. The positive influence between Return on Equity on stock returns, shows that investors use ROE contained in the issuer's financial statements as an analysis tool to obtain a decent stock return.

The results of this study support the research conducted by (Aziz, 2012)which examines the effect of Return On Equity on Stock Returns stating that a positive and significant effect on stock returns. This research is also supported by (Susilowati \& Turyanto, 2011)which states that Return On Equity has a positive and significant effect on stock returns.

\title{
Effect of Debt to Equity Ratio (DER) on Dividend Payout Ratio (DPR)
}

Based on the results of the above test it can be seen that both partially and simultaneously, the debt to equity ratio variable is normally distributed. The debt to equity ratio variable is also free from multicollinearity, autocorrelation and heteroscedasticity. The results obtained from the $t$ test showed a t-test value of 2,468 and a significance of 0.016 . The results obtained from the $t$ test show that the Debt to Equity Ratio (DER) has a significant effect on the Dividend Payout Ratio (DPR) in the property and real estate sector on the Indonesia Stock Exchange, where when the Debt to Equity Ratio (DER) of a company rises, the dividend payout the ratio will decrease, and vice versa, when the Debt to Equity Ratio (DER) decreases, the company's dividend payout ratio will riset (Sutrisno, 2009). Then Debt to Equity Ratio (DER) has a significant effect on Dividend Payout Ratio (DPR).

This is supported by research by(Afas et al., 2017), (Komrattanapanya \& Suntraruk, 2013), (Labhane \& Das, 2015), and(Yasa \& Wirawati, 2016), showing that DER has a significant (negative) effect on the dividend payout ratio where each increase from the debt to equity ratio causes a decrease dividend payout ratio. Meanwhile research results from(Rehman \& Takumi, 2012) show significant (positive) results from the debt to equity ratio to the dividend payout ratio, where any increase in the debt to equity ratio will cause an increase in the dividend payout ratio.

This is supported by research (Rehman \& Takumi, 2012) that shows significant (positive) results from the debt to equity ratio to the dividend payout ratio, where each increase in debt to equity ratio will cause an increase in the dividend payout ratio. While the research results from (Afas et al., 2017), (Komrattanapanya \& Suntraruk, 2013), (Labhane \& Das, 2015), and (Yasa \& Wirawati, 2016), show that DER has a significant (negative) effect on the dividend payout ratio. where each increase of the debt to equity ratio causes a decrease in the dividend payout ratio.

\section{Effect of Return on Equity (ROE) Against Devidend Payout Ratio (DPR)}

Based on the results of the above test it can be seen that both partially and simultaneously, the return on equity variable is normally distributed. The return on equity variable is also free from multicollinearity, autocorrelation and heteroscedasticity. The results obtained from the $t$ test show the value of $t$-count 3,994 and significant 0,000 . The results obtained from the $t$ test show that Return on Equity (ROE) has a significant (positive) effect on the Dividend Payout Ratio (DPR) of property and real estate listed on the Indonesia Stock Exchange, where when the company's return on equity rises the dividend payout ratio will rise also. Vice versa, when the return on equity decreases, the dividend payout ratio also decreases. This means that Return on Equity (ROE) has a significant (positive) effect on Dividend Payout Ratio (DPR) that can be accepted.

Companies that are able to generate profits and stabilize the level of profit to be obtained can determine how much dividend will be distributed to investors. The prospect of

\author{
p-ISSN 2337-571X | e-ISSN 2541-562X \\ (C) 2020 Edunomic: Jurnal Ilmiah Pendidikan Ekonomi \\ Fakultas Keguruan dan Ilmu Pendidikan
}


achieving profit next year is also a major factor in the number of dividends to be distributed this year. If management believes that it can make a profit next year, then it is certain that dividends will definitely increase.

As for the possibility of the emergence of even distribution of dividends, company management will continue to maintain stability and show shareholders in the form of signals (ie dividends), that dividends are still given by companies in accordance with market expectations. Motivation to distribute dividends will be high if the company can achieve high profits. This means that the motivation to distribute increased dividends is also determined by the company's management's confidence in achieving profits in the years to come (Gumanti, 2013: 85).

The results of this study are supported by research(Gumanti, 2013), (Komala \& Nugroho, 2013), (Sumampow \& Murni, 2016), (Kartika, 2015), (Yudiana \& Yadnyana, 2016)and Yasa et al (2016) show ROE has a significant (positive) effect ) to the dividend payout ratio where the increase in return on equity results in an increase in the dividend payout ratio. Meanwhile the results of research from (Komala \& Nugroho, 2013)and (Maladjian \& Khoury, 2014)show significant (negative) results from return on equity to the dividend payout ratio, where any increase in return on equity will cause a decrease in the dividend payout ratio.

\section{Effect of Dividend Payout Ratio (DPR) mediates Debt to Equity Ratio (DER) on stock returns}

Sobel test results show that, the Dividend Payout ratio can mediate the effect of Debt to Equity Ratio on stock returns on property and real estate companies listed on the Stock Exchange in the 2014-2018 period. Judging from the results of $t$ count $=2.296$ greater than $t$ table with a significance level of 0.05 that is equal to 1.96 , it can be concluded that the mediation coefficient 0.20862 is significant and means there is an effect of DER mediation on stock returns through the DPR.

A company with a low DER means that it has a low debt level as well, a low debt level is considered to be able to increase the company's revenue, if the company's revenue increases, the dividends distributed will also increase, this increase in dividends will also have an impact on increasing stock returns. An increase or decrease in debt will in turn affect the size of the net profit available to par shareholders including dividends received because the obligation to pay debts takes precedence over dividend distribution. Thus, the lower the debt ratio will further increase the profitability ratio of a company. The results of this research that support this research conducted by (Nazir et al., 2012)stated that there is an influence of leverage ratio (DER) on stock returns with dividends as a mediating variable.

\section{Effect of Dividend Payout Ratio (DPR) mediates Return on Equity (ROE) on stock returns}

Sobel test results show that, the dividend payout ratio can mediate the effect of return on equity on stock returns on property and real estate companies listed on the Stock Exchange in the 2014-2018 period. Judging from the results of $t$ count $=3.748$ is greater than $t$ table with a significance level of 0.05 which is 1.96 , it can be concluded that the mediation coefficient of 0.3601 is significant and means there is an effect of ROE mediation on stock returns through the DPR. 
A company with a high Return on Equity (ROE) means it has enough profit to pay dividends to its shareholders. The higher ROE, the dividends distributed to shareholders will also be higher, so stock returns will also go up. Dividend policy provides information about the company's profit growth in the future, this information will invite a response from investors which in turn will affect the company's return (Baah et al., 2014).

In accordance with the signaling hypothesis theory, it can be stated that the higher ROE shows that the company has a high profit as well, so this becomes good news or a good signal for investors and will have an impact on increasing dividends paid, thus also increasing stock returns. The results of previous studies that support this research conducted by Unggul (2013) stated that there is an effect of the profitability ratio (ROE) on stock returns with dividends as a mediating variable.

\section{Conclution}

The results of this study also show the influence of the ratio of debt to capital and equity to dividend stock loans as an intervening variable. The test results show that the DER variable (Debt to Equity Ratio) is not significant to stock returns. Return on Equity (ROE) has a significant positive effect on stock returns. Debt to Equity Ratio (DER) has a significant effect on Dividend Payout Ratio (DPR). Return on Equity (ROE) has a significant (positive) effect on Dividend Payout Ratio (DPR). Dividend Payment ratios can mediate the effect of the Debt to Equity Ratio on stock replacement. In evaluating the effect of mediation, it is proven that dividend policy can mediate the effect of ROE and DER on-stock returns.

\section{Referensi}

Afas, A., Wardiningsih, S. S., \& Utami, S. S. (2017). Pengaruh Cash Ratio, Return On Assets, Growth, Debt To Equity Ratio, Firm Size, dan Kepemilikan Institusional Terhadap Dividend Payout Ratio. Jurnal Ekonomi Dan Kewirausahaan, 17(2).

Agarwal, A., Azim, A., Ambesh, S., Bose, N., Dhiraj, S., Sahu, D., \& Singh, U. (2003). Salbutamol, beclomethasone or sodium chromoglycate suppress coughing induced by iv fentanyl. Canadian Journal of Anesthesia. https://doi.org/10.1007/BF03017801

Ariyanti, A. I. (2016). Pengaruh Cr, Tato, Npm Dan Roa Terhadap Return Saham. Jurnal Ilmu Dan Riset Manajemen (JIRM), 5(4).

Aziz, N. S. (2012). Pengaruh Return On Asset (ROA), Debt To Equity Ratio (DER), Tingkat Suku Bunga dan Tingkat Inflasi Terhadap Return Saham Sektor Perbankan di Bursa Efek Indonesia (PERIODE 2003-2010). Skripsi. Makassar: Universitas Hasanuddin Makassar.

Baah, B. K., Tawiah, R., \& Opoku, F. E. (2014). Industry sector determinants of dividend policy and its effect on share prices in Ghana. International Journal of Economics, Business and Finance, 2(5), 1-19.

Brigham, E. F., \& Houston, J. F. (2011). Dasar-dasar Manajemen Keuangan Terjemahan. Jakarta: Salemba Empat.

Gumanti, T. A. (2013). Kebijakan Dividen Teori. Empiris Dan Implikasi.

Halim, A. (2015). Manajemen Keuangan Bisnis Konsep dan Aplikasinya. Jakarta: Mitra Wacana Media.

Hartono, J. (2013). Teori Portofolio dan Analisis Investasi Edisi Kedelapan. Yogyakarta: BPFE.

Hery, S. E., \& Si, M. (2015). Analisis Laporan Keuangan Pendekatan Rasio Keuangan: Cetakan Pertama. Yogyakarta: CAPS.

p-ISSN 2337-571X | e-ISSN 2541-562X

(C) 2020 Edunomic: Jurnal Ilmiah Pendidikan Ekonomi Fakultas Keguruan dan Ilmu Pendidikan 
Horne, J. C. Van, \& Wachowicz, J. M. (2012). Prinsip-prinsip manajemen keuangan. Jakarta: Salemba Empat.

Horne Van, J. C., \& Wachowicz Jr, J. M. (2000). Fundamentals of Financial Management. Prentice Hall.

Kartika, A. V. (2015). Pengaruh Return On Assets, Return On Equity dan Assets Growth Terhadap Dividend Payout Ratio (Studi Pada Perusahaan Manufaktur Yang Terdaftar di Bursa Efek Indonesia Periode 2010-2012). Jurnal Administrasi Bisnis, 18(2).

Komala, L. A. P., \& Nugroho, P. I. (2013). The Effects of Profitability Ratio, Liquidity, and Debt towards Investment Return. Journal of Business and Economics, 4(11), 1176-1186.

Komrattanapanya, P., \& Suntraruk, P. (2013). Factors influencing dividend payout in Thailand: A tobit regression analysis. International Journal of Accounting and Financial Reporting, 3(2), 2162-3082.

Labhane, N. B., \& Das, R. C. (2015). Determinants of dividend payout ratio: evidence from Indian companies. Business and Economic Research, 5(2), 217-241.

Maladjian, C., \& Khoury, R. El. (2014). Determinants of the dividend policy: an empirical study on the Lebanese listed banks. International Journal of Economics and Finance, $6(4), 240-256$.

Nazir, M. S., Abdullah, M. M. N., \& Nawaz, M. (2012). How dividend policy affects volatility of stock prices of financial sector firms of Pakistan. EuroJournals Publishing Incorporation: American Journal of Scientific Research, 61(1), 132-139.

Nirayanti, L. P. R., \& Widhiyani, N. L. S. (2014). Pengaruh Kebijakan Dividen, Debt to Equity Ratio, dan Price Earning Ratio pada Return Saham Perusahaan LQ 45 Periode 2011-2013. E-Jurnal Akuntansi, 803-815.

Nurmasari, I. (2017). Analisis Current Ratio, Return On Equity, Debt to Equity Ratio dan Pertumbuhan Pendapatan Berpengaruh Terhadap Return Saham Pada Perusahaan Pertambangan Di Bursa Efek Indonesia 2010-2014. Jurnal Kreatif, 5(1), 112-131.

Pratiwi, P. (2018). Pengaruh Struktur Kepemilikan Terhadap Nilai Perusahaan dengan Kebijakan Hutang sebagai Variabel Intervening (Studi Kasus Perusahaan Property dan Real Estate yang Terdaftar di Bursa Efek Indonesia). Universitas Islam Negeri Alauddin Makassar.

Priyonoto, B., Wibowo, A. S., \& Diarsyad, M. I. (2018). Pengaruh current ratio, debt to equity ratio, return on equity terhadap return saham pada perusahaan consumer goods yang go public di bursa efek indonesia tahun 2013-2016. FEB UPR.

Rehman, A., \& Takumi, H. (2012). Determinants of dividend payout ratio: Evidence from Karachi Stock Exchange (KSE). Journal of Contemporary Issues in Business Research, 1(1), 20-27.

Sari, N. A. A. (2015). Analisis Pengaruh Debt Equity Ratio Dan Return On Equity Terhadap Return Saham Dengan Nilai Perusahaan Sebagai Variabel Moderating. Universitas Muhammadiyah Surakarta.

Sartono, A. (2014). Manajemen Keuangan Teori dan Aplikasi Edisi 4 Cetakan Ke-8. Yogyakarta. Penerbit BPFE.

Shim, J. K., \& Siegel, J. G. (1999). Operations management. Barron's Educational Series.

Siburian, F. E. (2013). Analisis Pengaruh DER, ROA Terhadap Return Saham Pada Perusahaan Perbankan yang Terdaftar di BEI. Jurnal Ekonomi \& Keuangan, 1(6), 2532.

Sumampow, S., \& Murni, S. (2016). Pengaruh Return Saham, Price Book Value Dan Return On Asset Terhadap Dividend Payout Ratio Pada Perusahaan Yang Terdaftar Di BEI

$p-I S S N \underline{2337-571 X} \mid e-I S S N \underline{2541-562 X}$

(C) 2020 Edunomic: Jurnal Ilmiah Pendidikan Ekonomi Fakultas Keguruan dan Ilmu Pendidikan 
(Studi Pada Perusahaan Telekomunikasi). Jurnal EMBA: Jurnal Riset Ekonomi, Manajemen, Bisnis Dan Akuntansi, 4(2).

Susilowati, Y., \& Turyanto, T. (2011). Reaksi signal rasio profitabilitas dan rasio solvabilitas terhadap return saham perusahaan. Dinamika Keuangan Dan Perbankan, 3(1), 17-37.

Sutrisno, H. (2009). Manajemen keuangan teori, konsep dan aplikasi. Yogyakarta: Ekonosia.

Syamsudin, L. (2011). Manajemen Keuangan Perusahaan, PT. Raja Grafindo Persada, Jakarta.

Tandelilin, E. (2010). Portofolio dan Investasi: Teori dan aplikasi. Kanisius.

Van Horne, J. C., \& Wachowicz Jr, J. M. (2005). Prinsip-prinsip Manajemen Keuangan. Edisi Kedua Belas. Jakarta: Salemba Empat.

Yasa, K. D. M., \& Wirawati, N. G. P. (2016). Pengaruh Net Profit Margin, Current Ratio, dan Debt to Equity Ratio pada Dividend Payout Ratio. E-Jurnal Akuntansi, 921-950.

Yudiana, I. G. Y., \& Yadnyana, I. K. (2016). Pengaruh Kepemilikan Manajerial, Leverage, Investment Opportunity Set dan Profitabilitas Pada Kebijakan Dividen Perusahaan Manufaktur. E-Jurnal Akuntansi, 111-141. 